effect of an emetic is not only to produce relaxation of the whole body, but also to increase the sccretion of bile: this increased secretion of bilc if its exit is prevented, will mechanically increase the distension of the duct, and thus will a passage be opened for the calculus. If this position be true, it will follow that an emetic cannot assist the expulsion unless there is a total stoppage of the duct; for without this, the bile would pass off and no distension take place. The frequent failure of emetics, in makıng any impression on the disease, sutficiently argues a modification of the complaint over which they have no power. 'This modification l lake to he that state when the stone, in consequence of its angles, does not completely close the duct."

In the case above related, the gall stone that passed per anum, and which is now in my possession, has a smooth round surface, and therefore, according to Pemberton was well formed for propulsion by the act of vomiting. It is of an oval shape measuring nearly two inches in length, and bears some resenblance to an English walnut. On dividing it longitudinally with a small saw, I found it composed of concentric laminx, thinncr and barder near the surface, and its centre solt, of looser texture, and wearing a chrystalized appearance.

Pemberton says "the size of gall-stones, which have passed without destroying the patient, almost exceeds belief. I have in my possession the model of one, whose long diameter is two inches and a quarter, and whose short diameter is one inch and a quarter. The patient from whom this passed suffered for five months the most acute pain. From the magnitude of the stone, I should believe that ulceration (in consequence of inflammation) had taken place between the duct and duodenum, and that thus an aperture was made for the stone to pass into the intestines, as it is unlikely that the duct could admit of such distension."

What Dr Pemberton conjectured was verified in this case, as I am satisfied by a re-examination of the morbid parts, which I now have preserved.

For the consideration of those who may become Members of Legis. latures.

[Communicatod for the New-England Journal of Medicine and Surgery.] GENTLEMEN,

QUPPOSE the human bones, or the more recent suhject, should happen to fall into the hands of some one, whose 
duly might make it necessary to perform certain experiments upon them; and suppose such person should happen to know thit those bones, or other remains of the human body, were procured cautiously, and with a view not to disturb the public graves, hut illegally; should this knowledge alone be a reason why, if he uses them, he should be decmed guilty of a crime of a felonious nature, and of so high a grade, as to make it just, that he should be punished like a felon in Newgate prison, for ten years or less, and pay a heavy finc. Such it is believed must be the operation of a Law of Connecticut, passed in 1824.* The law in question scems to be predicated upon the mistaken idca, that the act of taking or removing a dead body secretly from the grave is theft. The propricty of this may well be doubted. For it is evident such hody cannot be regarded as property that is and may be useful to every one, or like' money that is easily transferable from one person to another, and useful to each possessor. Neither is it owned by any one. And the grave clothes, if taken, are property to which the former owner or owners have resigned all claim. For it is obvious that no further use of said property is intended. This act may or may not be a trespass, according to the circumstances of the case. It is admitted, however, that it is sometimes so foolishly and imprudently done, as to be the cause of producing great mischief and excitement; and the person who does it, should in such case be punished according to the damage done. He should be punished, however, for disiurbing the public peace; not for injuring the dead body.

It would be difficult to show that the policy of law requires that the privately removing the dead hody from the grave should be regarded in the same light as theft. For the indignation of the more ignorant part of the publick, and of the relatives of the diseased, even in the most civilized state of society, which is excited by the discovery of this act, is experimentally proved often to he greal. This cause alone, soon without the aid of law, is abundantly sufficient, in general, to insure a sufficient degree of caution in the means made use of to obtain subjects. And no one, it is presumed, would pretend it was immoral to dissect the human body, provided it is clone with correct motives, and so secretly as not to disturb the feelings of any one. The doing a thing secretly, can be no crime, unless the thing itself, is an improper one to be done.

The whole history of anatomy and surgery will show that the business of dissection is carried on extensively in every

"Sce the Law. 
scientific country, and by men of the purest morals, and greatest humanity. And the history of general sociely will show, that this very uscful business is managed with so much prudence, that the peace of society is but seldom disturbed thereby.

The contemplation had in the formation of the late law evidently was, that those who might find motives to wish to eviade the law, would be very artful in effecting that object, But it should have been considered also that those motives are not those of a felon, arising from a wish to injure sociely, but grow out of motives of an entirely opposite character, and such as are commendable in the highest degree, namely, a wish to acquire the power of benefiting the living. It has been admitted, however, that such persons should be liable in damages for wantonly or even imprudently injuring the feelings of any one. The dead they cannot injure. Our whole cunduct, and all our regulations and laws on this delicate subject, especially should be coolly, humanely, and prudently managed, having reference to the benefit, the rights, the feelings, and the associations of the living; for the dead, on their own account, require no protection. 'The truth is, our fellow feelings, and associations towards the living, continue to be exercised towards them, when dead. 'This is of no importance in any way. as respects the dead, but is often a fruitful source of evil, as well as good, to the living. And men of the most cultivaled minds seem not to be sufficiently aware of this, when they make laws on this subject. There is another truth which should not be forgotten; namely, those whose duty it may be to dissect the human body, have a right to claim the protection of law, as well as other citizens, provided they conduct their business properly.

Blackstone.

Connecticut.

\section{MISCELLANEOUS NOTICES.}

Diagnostic between Irritation and Inflammation of the Mucous Membranes of the Bronchice.-M. NAuche has remarkid that, in the natural state, or where there only exists an excess of irritation, the matters secreted by the different mucous membranes have always a well-marked acidity : while, on the other hand, if these membranes be inflamed, alterations of their vital properties supervene; the nature of the secretion is chan ted, and becomes alkaline. These two states are e isily rorog ised by a morsel of paper tinged blue by turnsol. When the matter 